\title{
A Legalização da Classe Trabalhadora Brasileira na Perspectiva de Bernard Edelman
}

\author{
Marcelo Tolomei Teixeira \\ Doutorando em Direitos e Garantias Fundamentais pela \\ FDV. Mestre em Filosofia do Direito pela Universidade \\ Federal de Santa Catarina (UFSC). Juiz do Trabalho na \\ 17ª Região - Espírito Santo. tolomei@trt17.gov.br
}

\section{Daury Cesar Fabriz}

Doutor e mestre em Direito Constitucional pela UFMG. Professor-associado do Departamento de Direito da Universidade Federal do Espírito Santo (Ufes). Coordenador e professor do Programa de Pós-Graduação em Direitos e Garantias Fundamentais da Faculdade de Direito de Vitória (FDV), sociólogo e advogado. dauryfabriz@terra.com.

\section{Resumo:}

0 presente trabalho faz uma abordagem sobre a obra de Bernard Edelman (2016) - A Legalização da Classe Operária - que analisa os direitos trabalhistas como uma forma perspicaz encontrada pelo capital para neutralizar a luta de classes. A análise é feita tendo como base a instituição dos direitos sociais no Brasil por meio da Era Vargas. De fato, todo o arcabouço da ideologia - externada pelos peritos sociais - tinha a luta de classe como um mal a ser rejeitado. 0 tema tratado por Edelman, ou seja, direitos sociais sob o panorama das concessões revolucionárias, há de ser analisado sob 0 novo enfoque neoliberal dos presentes dias quanto à defesa de tais direitos e, independentemente de sua veemente crítica, merece a defesa da sociedade sob pena de se caracterizar um verdadeiro déficit civilizatório. Como metodologia, utilizou-se o materialismo histórico-dialético para discutir acerca da pretensão da ideologia do capital em negar a luta de classes mediante os discursos jurídicos que serão apontados.

Palavras-chave: Direitos trabalhistas. Revolução. Era Vargas. Neoliberalismo. 


\title{
The Legalization of the Brazilian Working Class \\ in Bernard Edelman Perspective
}

\begin{abstract}
This article is an approach to the work of Bernard Edelman - The Legalization of the Working Class - which analyses labor rights as a shrewd way found by capital to neutralize the class struggle. The analysis is based on the implementation of social rights in Brazil by Vargas. Indeed, the whole framework of the ideology - externalized by social experts - had the class struggle as an evil to be rejected. The subject treated by Edelman, the social rights in the prospect of revolutionary concessions, must be examined under the new neoliberal approach of the present day in relation to the defense of such rights and, regardless of its vehement criticism, deserves the protection of society under the penalty of characterization of a true civilizational deficit. The methodology used is the dialectical historical materialism used to discuss the pretension of the capital ideology in denying the class struggle through legal discourses that will be appointed.
\end{abstract}

Keywords: Labor rights. Revolution. It was Vargas. Neoliberalism.

\section{Sumário:}

1 Introdução. 2 A Transição da Velha República para o "Estado-Novo". 3 Os Discursos do Estado-Novo dos ideólogos do Estado Novo: legitimação da ordem trabalhista. 4 As Consequências. 5 Considerações Finais. 6 Referências. 


\section{INTRODUÇÃO}

Hoje o homem que trabalha,

para servir seu patrão

sabe que tem suas férias

boa remuneração

e chegada a invalidez

recebe sua pensão.

Mas antes de vir Getúlio

recebia como férias

Ponta-pés e bofetão (PARANHOS, 1999, p. 169). ${ }^{1}$

Segundo Bernard Edelman (2016, p. 8), jurista e filósofo francês, crítico da política de consenso dos movimentos operários com a social-democracia, as conquistas sociais da classe operária, como jornada de trabalho, férias remuneradas, estabilidades, etc., significaram, na prática, o abandono da ambição revolucionária ante a aliança de classes do capital e do trabalho - o sistema jurídico capitalista ao legalizar a classe trabalhadora acaba por neutralizá-la, em sua fase mais avançada de conscientização da classe operária na perspectiva da luta revolucionária - conforme a práxis marxista.

O ambiente de colaboração capital-trabalho é notório na social-democracia e seu paradigma do Estado social. Paradigma, que conheceu a partir da Segunda Guerra Mundial um momento de ouro do capitalismo, com desenvolvimento, direitos sociais com estipulação de variados deveres ao Estado (saúde, moradia, cultura, etc.) e um desenvolvimento sem igual da sociedade salarial e seu correspondente direito do trabalho - inclusive agregou em seu campo diversas categorias, como dos funcio-

1 Poesia de cordel de Delarme Monteiro da Silva lançada em 1950 para campanha presidencial de Getúlio Vargas transcrita por A. Paranhos. 
nários públicos e liberais - que reivindicaram o status de trabalhadores ante a força de tal estatuto. Bem verdade que, com a ascensão neoliberal, a dialética é de um Estado que se torna cada vez mais mínimo no campo social e de um direito do trabalho que tende a perder cada vez mais sua força de proteção. As esquerdas não conseguiram até agora uma resposta potente ao neoliberalismo. Como explica Nay (2003, p. 475), não há recursos para o Estado Social que cada vez mais privatiza empresas públicas, diminui gastos com a saúde, a educação, o transporte e que tem que tratar de temas espinhosos como inflação de preços, fugas de capitais, enfraquecimento da moeda e aumento do déficit público.

O problema deste artigo, nesse contexto, é buscar responder se os discursos advindos com a chamada Era Vargas cabem no figurino sugerido por Bernard Edelman, isto é, oferecer direitos desde que a classe trabalhadora se comprometesse a colaborar com uma política muitas vezes de austeridade econômica e submissão à autoridade fabril e que - principalmente abstivesse do chamado "perigo vermelho", ou seja, que não se inclinasse para os movimentos comunistas ou anarquistas? Há de se questionar se este conceito negativo dos direitos trabalhistas apresenta-se em contexto neoliberal quando o capital deseja justamente desregulamentar os mercados de trabalho?

Os objetivos do artigo são: análise da conjuntura em que surgiram os direitos trabalhistas no Brasil - em especial a transição da Velha República para a Nova República - com ascensão da geração de Vargas ao poder e a instituição de seu modelo de legislação trabalhista; análise dos discursos dos peritos da Era Vargas em comparação com a análise que Bernard Edelman faz sobre a ideologia do direito do trabalho em contraste com os ideais revolucionários; analisar, por fim, as críticas veementes de Edelman aos direitos trabalhistas diante do contexto neoliberal de desregulamentação dos mercados de trabalho. 
O método preconizado é o materialismo histórico dialético - que segundo Bottomore (1983, p. 262) parte dos interesses materiais das classes sociais que levam à luta de classes, com os antagonismos podendo não ser notados ou serem mistificados pela ideologia. No caso específico, a ideologia do capital pretende justamente negar a luta de classes por meio dos discursos jurídicos que serão levantados.

Neste texto situamos o momento histórico em que os discursos são produzidos, suas essências, ou seja, as figuras de neutralidade que lhes são recorrentes e, finalizando, as consequências e também a sustentação da possibilidade da tese crítica de Edelman diante do contexto neoliberal.

\section{TRANSIÇÃO DA "VELHA REPÚBLICA" PARA O ESTADO NOVO}

A sociedade escravista brasileira tinha o escravo funcionando com força bruta sem qualquer regulamentação de trabalho, uma vez que os trabalhadores não escravos também sofriam os reflexos de uma sociedade autoritária que impunha caráter privado total para tratar com a força de trabalho - aliás, esse tratamento desumano com certeza influenciará em muito a formação do caráter de nossas elites no tratamento dispensado aos trabalhadores subordinados. A formação de nosso mercado de trabalho está marcada por um forte preconceito racial: os negros eram "vagabundos" e "macumbeiros", os italianos os "carcamanos" e os nordestinos quando migraram - especialmente para São Paulo - são os “baianos”, apelidos com forte carga de ideologia preconceituosa das classes dominantes.

As primeiras intervenções estatais no mercado de trabalho foram as legislações de descravizações no final do século 19 e mostram nosso descompasso com o capitalismo central que já apontava para realizações de certos direitos sociais como de proteções às crianças, acidente de trabalho, caixas de assistência, entre outros. 
Como o trabalho escravo estava em descompasso com o sistema capitalista, uma vez que representava a esterilização do capital, não sendo mais compatível com as condições de acumulação moderna. Por tais sentidos econômicos, o Brasil partiu para a extinção dos escravos em 1850 e abolição em 1888. No campo jurídico foi revogada a Lei de Locação de Serviços (1890) - extremamente severa com os prestadores - pelo Decreto n. 1.162, de 12 de dezembro, que, em tese, representava uma liberdade maior na prestação do trabalho, dado que o referido diploma legal previa prisão de um a três meses para a suspensão do trabalho por melhores condições - a rigor: a greve. Na verdade, tudo isso se prestava para "substituir o negro pelo branco" ante os financiamentos estatais para introdução do colono estrangeiro principalmente em São Paulo que era o Estado potencializador do ciclo do café.

Explica Pochmann (2014, p. 24) que a abolição do trabalho escravo, sem reforma agrária, e ante o ingresso em massa do imigrante europeu, fez surgir uma quantidade considerável de trabalhadores sobrantes - este foi o cenário do início de nosso mercado de trabalho. $\mathrm{O}$ ciclo de café em São Paulo, necessitando de braços, contratou os trabalhadores imigrantes italianos - optando em não utilizar os libertos, ao contrário de Minas Gerais e Rio de Janeiro - e aí por diversas razões - que vão do preconceito e ao fato de o nordestino, por exemplo, ainda estar ligado à terra.

O trabalhador do campo - o imigrante que plantava café - tinha, na maioria das vezes, a permissão para produzir uma pequena agricultura de subsistência. Daí não haver um mercado de trabalho propriamente dito no molde capitalista em que o salário é a única prestação do empregador. Com a industrialização, tais características vão sendo notadas. O início do mercado de trabalho livre, principalmente no centro urbano de São Paulo e timidamente no Rio de Janeiro - assim como o começo da Revolução Industrial na Inglaterra e Bélgica - era marcado pela ausência de uma legislação trabalhista, forte exército de reserva (trabalhadores sobran- 
tes, pequenos biscateiros), forte utilização de mulheres e crianças e sem qualquer perspectiva de segurança no emprego - posto que as pequenas e médias empresas - que eram preponderantes - contratavam a mão de obra de acordo com a realidade de encomendas.

A Revolução de 30 rompe com a hegemonia da cultura do café e adentra forte na questão social. Há ampliações dos direitos trabalhistas e criação da Justiça do Trabalho - seu embrião são as chamadas Comissões Mistas de Conciliação advindas com o Decreto 21.396, de 12 de maio de 1932. A chamada legalização da classe trabalhadora rompe, ainda que acanhadamente, com o isolamento da classe operária brasileira. A par da forte resistência do empresariado são reconhecidos diversos direitos materiais, como a lei de férias, restrição ao trabalho infantil, jornada de 8 horas e respeito às convenções coletivas. Por outro lado, temos os sindicatos reprimidos e ao mesmo tempo o aparato sindical caminhando para o campo estatal. A Constituição de 37 considera a greve como um delito.

A luta de classes, que é razão de ser da classe operária - segundo Edelman (2016, p. 112), que se conjuga com sua liberdade, e que não pertence a ninguém, senão a ela mesma, é aprendida. As massas devem obediência ao Estado assim como a seus sindicatos. Planejamento, eficiência, ordem e subordinação são as exigências do Estado Novo. Fora disso temos os selvagens - daí a obediência aos dirigentes e ao Estado.

O modelo de Vargas, independentemente de se discutir sua inclinação ao corporativismo ou mesmo ao fascismo italiano - intensamente já debatida pela Sociologia, História e Ciências Políticas - terá uma descrição objetiva de acordo com os limites do presente artigo. Um dos pontos-chave do modelo era fazer com que a negociação direta entre capital e trabalho fosse esvaziada - uma vez que conflituosas. Por tal razão, a Justiça do Trabalho faria a conciliação ou solucionaria tais conflitos. Tudo se 
tornaria uma questão legal e não uma luta de classes em que o poder de barganha pelejaria até um acordo possível - o Estado assume de forma categórica o poder de solução.

A lei, por si só, já criara uma rede de segurança: direitos mínimos a serem observados. Reivindicações além das leis mereceriam uma sentença de procedência ou não. Os sindicatos - colaboradores do governo - teriam a missão de ajudar na instituição das políticas governamentais nos campos econômico e social. Diante de tal cenário, os sindicatos seriam únicos, com total monopólio de representação de categorias profissionais de acordo com a geografia do estabelecimento (mínimo de um município), só estes poderiam assinar acordos coletivos (válidos para toda categoria, independentemente da associação) e seriam, ainda, beneficiados pelo imposto sindical - que também era obrigatório para toda a categoria.

Vargas e sua geração de peritos (Oliveira Viana, Joaquim Pimenta, Evaristo de Moraes, etc.) anteciparam a solução dos conflitos dos trabalhadores urbanos. No campo nada mudou, uma vez que o modelo político tinha ligações com os “coronéis” - os grandes latifundiários. O historiador Manoel Maurício de Albuquerque (1986, p. 590) aponta que os fazendeiros tinham vastas experiências de controle social com a classe proprietária, ao contrário dos empresários urbanos, que diante da nova industrialização conheceram de forma perplexa o sindicalismo, a greve, a luta por acordos e convenções coletivas, etc.

O Estado assume o papel de julgador dos novos conflitos sociais urbanos e legaliza - conforme conceito de Edelman - a classe trabalhadora brasileira. Faz um verdadeiro estardalhaço de tal movimento. Ainda segundo Edelman (2016, p. 8), o Estado nada mais fez do que colocar um direito que se ajusta ao trabalho, astúcia do capital - aqui podemos dizer, astúcia de Getúlio Vargas e de seus peritos que, usando as argumentações de Edelman, também deram à classe operária brasileira uma língua que não é sua. 
Paranhos (1999, p. 112) demonstra como o Estado Novo apresenta propaganda massiva tecendo loas à nova legislação social. Marcondes Filho (ministro do Trabalho à época), imediatamente passou a utilizar a "Hora do Brasil", com palestras semanais - ritualizando verdadeiras aulas - de dez minutos de duração, denominadas "Falando aos Trabalhadores Brasileiros" - discorrendo sobre os novos direitos trabalhistas na "Hora do Brasil”. Isso quando não era o próprio Getúlio Vargas que criou a famosa saudação "Trabalhadores do Brasil”, personificando, cada vez mais, sua figura de doador e protetor da classe trabalhadora urbana.

O Brasil entra na Segunda Guerra Mundial e curiosamente foi o governo de Getúlio que promoveu a primeira flexibilização ou mesmo desregulamentação (como os neoliberais modernos hoje propõem). Em agosto de 1942, com o Decreto-Lei n. 4.637, foram autorizadas: a prorrogação da jornada normal de trabalho nas empresas que interessavam, ao critério do governo, à produção e à defesa nacional; o Decreto-Lei n. 4.869, dispensava os industriais do cumprimento da lei de férias às empresas tidas como essenciais à segurança nacional; o Decreto-Lei n. 4.937 impedia a mobilidade do trabalhador (transferência de emprego) nas chamadas indústrias de guerra, com penas em caso de falta ou abandono do serviço: trabalhadores brasileiros que infringissem seus dispositivos seriam tomados por “desertores”, e, no caso de estrangeiros, se naturais dos países com os quais o Brasil estava em guerra, seriam considerados “sabotadores”. Por seu turno, o Decreto-Lei n. 5.821, de 16 de setembro de 1943, que vigorou até fevereiro de 1945, praticamente impossibilitou a instauração de dissídios.

Cabe relembrar que o artigo 139 da Constituição da época considerava a greve como recurso antissocial, com pena de prisão capitulada pelo Código Penal. Nesse conturbado momento, houve, ainda, a instauração do 
imposto sindical pelo Decreto-Lei n. 2.377, de 8 de julho de 1940, que tinha como objetivo combater a "falta de espírito agremiativo" do proletariado brasileiro.

Com o imposto sindical e o atrelamento dos sindicatos ao Estado, são poucos ou mesmo inexistentes os sindicatos combativos - daí a figura do "pelego" - que acomodado no seu papel de dirigente sindical a rigor não mobilizava a categoria para o embate com o capital - o que, geralmente, não fugia aos interesses do regime.

A polícia de Vargas encarcerava e batia nas lideranças que fugiam do modelo de ordem estabelecido. O enquadramento legal da classe trabalhadora foi feito à base do chicote, mas toda uma retórica foi elaborada para legitimar o movimento de enquadramento como o melhor caminho a ser seguido, pois, do contrário, estaríamos à deriva com a luta de classes, anarquia e violência. Passamos, então, para a análise dos discursos.

\section{OS DISCURSOS DOS IDEÓLOGOS DO ESTADO NOVO: Legitimação da Ordem Trabalhista}

A bandeira da legislação trabalhista era sempre desbravada nos discursos de Vargas e seus peritos da área social. Sabia tal geração de políticos utilizar os meios de comunicação modernos, em especial o rádio, no mesmo estilo dos nazistas. A bandeira da legislação social de fato impregnou sua marca, e até recentemente seu legado foi disputado por partidos políticos - sendo do conhecimento geral que após a abertura política no Brasil (o regime militar tinha imposto o bipartidarismo - MDB e Arena) o retorno da sigla PTB - o partido de Vargas - foi disputado por facções políticas. Francisco Campos - um dos técnicos mais competentes 
e conservadores do regime, citado por Paranhos (1999, p. 29), inaugura as transcrições dos discursos justamente apostando na força e tática da propaganda:

É possível hoje, e é o que acontece, transformar a tranquiila opinião pública do século passado em um estado de delírio ou alucinação coletiva, mediante os instrumentos de propagação, de intensificação e de contágio de emoções, tornados possivieis precisamente graças ao progresso que nos deu a imprensa de grande tiragem, a radiofusão, o cinema, os recentes processos de comunicação que conferem ao homem o dom aproximando ao da ubiqüidade, e, dentro em pouco, a televisão, tornando possível a nossa presença simultânea em diferentes ponto do espaço. Não é necessário contato físico para que haja multidão.

Observa Paranhos (1999, p. 142) que, por ocasião da solenidade da criação do Ministério do Trabalho, o empossado - ministro Lindolfo Collor - no cargo de 26.11.30 até 04.04.32 - trata de aduzir que "É o Ministério do Trabalho, especificamente, o Ministério da Revolução”. Apregoando então um capitalismo de visão humana, do solidarismo jurídico e cristão, no fundo um governo que resolve a luta de classe com violência e direitos. Com paz e harmonia, significando a colaboração de classe o país vai progredir com Getúlio Vargas como santo padroeiro de todas essas mudanças.

A produção dos discursos obedece a mesma linha de um fair play entre capital e trabalho, com a perspectiva apresentada por Edelman (2016) de que a classe trabalhadora estando legalizada estaria neutralizada. Edelman faz suas críticas desconstruindo os discursos jurídicos das decisões do poder Judiciário francês - que têm como tônica a greve tendo de respeitar os limites da propriedade e as comissões de fábricas não podendo receber visitas de partidos políticos, pois restritas às questões sindicais, isso em um contexto de um partido comunista (PCF) fortíssimo e movimento sindical atuante. E mesmo em tal ambientação, conclui Edel- 
man que a classe operária foi cooptada pela doutrina jurídica do capital - a rigor tais críticas são coerentes com os questionamentos advindos a partir de 1968 com o autoritarismo do cotidiano nas empresas e a burocratização do movimento sindical.

O Brasil da década de 30, com um governo central autoritário e com um movimento operário incipiente e cada vez mais atrelado ao Estado - se seguirmos a lógica de Edelman, tem os discursos que perseguem os mesmos objetivos: abandono dos trabalhadores de qualquer ambição revolucionária - legalizar e neutralizar são observados nos discursos de ambas as décadas e em regimes políticos bem distintos. É como se a linguagem do capital fosse universal: os direitos trabalhistas (conquistados ou concedidos) pressupõem o esvaziamento da luta de classes.

O Estado Novo autoritário - ao estilo fascista da moda - preservava o capitalismo abolindo a esfera política das relações trabalhistas - negando a luta de classes e, de forma mais rígida do que os modelos clássicos da social-democracia - até as barganhas diretas do capital com o trabalho. Táticas que solapam ou contornam, por meio da "astúcia” do capital que, conforme demonstra Edelman, solapa ou contorna a luta de classe via instituições democráticas, institutos jurídicos, meios de comunicação e pela passividade das massas.

O professor Paranhos (1999, p. 91) apresenta uma sucessão de trechos que vão justamente ao encontro dos supramencionados objetivos, e no caso brasileiro, de forma mais sistemática, é apresentada uma espécie de estado da natureza ao estilo de Hobbes, em que os grevistas selvagens, sem lideranças, os bestas-feras são neutralizados, e então passamos a ter uma sociedade em grau excelente - bastando para tal seguir os cânones do Estado Novo: 
O Governo não deseja, em nenhuma hipótese, o dissídio das classes, nem a predominância de uma sobre as outras, ou melhor, o Estado não quer, não reconhece luta de classes. As leis trabalhistas são leis de harmonia social (Getúlio Vargas).

O Presidente afastou de nosso país a ameaça que se vinha assustadoramente materializando. Convertendo em cidadãos, os integrantes de uma classe operária que só guardava memória de violências e de vexatórias humilhações, finalmente se conseguiria a imunização do operário brasileiro contra a infecção bolchevista (Azevedo Amaral).

O brasileiro tem índole efetiva. Mas antes de 30, andávamos jungidos a velhas doutrinas individualistas [...] o Estado, entre nós, exerce a função de juiz nas relações entre empregados e empregadores, porque corrige excessos [...] a nossa legislação social não veio em volta com o crepe das viúvas e a lágrima dos órfãos, mas em honra do lar proletário [...] na primeira, a figura de Leão XIII, inspirador da Justiça social no mundo moderno. Na segunda, a esfinge de Getúlio Vargas, instaurador da Justiça social no Brasil. Um conclui; outro aplica (Marcondes Filho). Enquanto países já afetos a uma legislação do trabalho se revolucionam atualmente com a implantação da lei de férias remuneradas, dos contratos coletivos, nós incorporamos esses institutos ao nosso direito escrito sem uma luta, sem um choque de classe (Salgado Filho).

É dentro deste quadro que se promoverá a figura de Getúlio como o "doador" da legislação social; todo o sangue escorrido pelos trabalhadores, em seus espaços de greves e mobilizações em curso na "Velha República" há de ser esquecido. O Estado-Novo funda um novo tempo, de harmonia social e colaboração de classes, e todo esse discurso funde-se com uma prática de intensa repressão para parte do movimento sindical que não deseja recapitular.

Getúlio Vargas é apresentado, nos discursos produzidos à época, como uma unanimidade, o Estado-Novo é democrático porque se preocupa com o social, de nada valeu a "Velha República" com seus ideais de representação, pois só gerou o “caos”, o Estado tem, na verdade, de 
intervir para gerar o desenvolvimento econômico e o cidadão é quem trabalha. Eis a cartilha do estado-novista, cuidadosamente controlada pelo Departamento de Imprensa e Propaganda (DIP), que tinha a função de divulgação e de censura. Conforme aduz Barthes (1978, p. 12) "[...] a lógica do fascismo não é impedir de dizer, é obrigar a dizer”.

Aponta Wolkmer (1989, p. 47) que a originalidade, o chamado "mito da doação" dos direitos trabalhistas como obra oriunda exclusivamente de Getúlio Vargas, é questionada por intérpretes de peso, como Evaristo de Moraes Filho, em seu clássico e desmistificador O Problema do Sindicato Único no Brasil, quanto por Ângela de C. Gomes, em Burguesia e Trabalho; Política e Legislação Social no Brasil - 1917-1937 posto que para tais autores citados a era varguista não foi o ponto inicial da legislação trabalhista $\mathrm{e}$ previdenciária. O mito da doação é ofensa aos trabalhadores que com suas greves e mobilizações antes de 30 , contrastam com a realidade corrupta do imposto sindical e de falsos líderes - os pelegos - que manipulados pelo Ministério do Trabalho representavam uma classe trabalhadora sem iniciativa.

O problema social já era sentido na Velha República, que também reprimia os movimentos sociais, mas que promulgou uma série de direitos trabalhistas também legalizando a classe trabalhadora desde os primórdios da formação do mercado de trabalho pátrio - citamos como exemplos: as leis sobre acidente de trabalho, de férias e a existência de um Código de Menores, constituindo-se tema de lutas e debates incansáveis dos trabalhadores desde a República Velha.

Os peritos sociais varguistas produziram um discurso social do Estado com o objetivo de cooptação dos trabalhadores. Com utilização de símbolos de fácil articulação: CLT, Justiça do Trabalho, CTPS e o $1^{\circ} \mathrm{de}$ maio com pompas e desfiles - à sua maneira a Era Vargas dá dignidade à classe trabalhadora - a construção da identidade do trabalhador era criada como nunca. 
A ideologia varguista apresentava a luta de classe como alienígena - fruto das concepções dos anarquistas e comunistas estrangeiros. Os culpados, os selvagens ou "bestas feras" foram localizados. Por tais motivos, o trabalho estrangeiro - que Vargas tanto promoveu - passou a ser restringido - verdade que já havia condições econômicas para tal. Aduz Paranhos (1999, p. 89) que Lindolfo Collor afirmara, em 26 de dezembro de 1930, de maneira emblemática, que "é tempo de substituirmos ao velho e negativo conceito de luta de classes pelo conceito novo, construtor e orgânico de colaboração de classes". Disso decorreria "proteção" do trabalhador nacional consubstanciada na "lei dos dois terços". ${ }^{2} \mathrm{Na}$ verdade, ao condenar que o estrangeiro tomasse o lugar do operário nacional, ele tinha em mira, em grande parte, o "perigo" representado pela difusão de "propagandas subversivas”.

\section{AS CONSEQUÊNCIAS}

Edelman (2016, p. 147), após expor todas as críticas ao modelo de cooptação que a social democracia engendra com a classe operária, apontando que a aliança entre capital e trabalho é o abandono dos trabalhadores do ideal revolucionário e a sua total colonização e neutralização, aduz não ignorar que muitos o tacharão de "pessimista”, muitos o criticarão por ter visto apenas o lado "ruim" das coisas. Diz não ser prondhoniano e que, portanto, a existência do "lado ruim" não implica que haja um "lado bom". Acreditar, porém, que a história avança pelo "lado ruim" - de acordo com que Hegel chama de trabalho do negativo, e Freud, do trabalho da morte.

2 Tal dispositivo encontra-se inserido na CLT nos artigos 352 e seguintes, que determina a proporcionalidade de $2 / 3$ entre empregados brasileiros e estrangeiros; contudo, a maioria dos autores entende que tal dispositivo foi revogado pela novel Constituição que equiparou o brasileiro e o estrangeiro residente no Brasil como iguais perante à lei (art. $5^{\circ}$ ). 
Não é original tal crítica sobre as cooptações da classe operária no cenário social democrata, dado que muitos autores - dentro de uma tradição marxiana - já o fizeram e fazem - a lista sugere o próprio Marx - com suas críticas, por exemplo, aos direitos do homem - vide em especial a questão judaica. O pensador alemão conheceu as novidades advindas com as ideias de "liberdade, igualdade e fraternidade". De acordo com a professora Thamy Pogrebinschi (2009, p. 375), contudo, Marx identifica nos direitos consagrados pela Revolução Francesa a separação entre cidadão e o homem e, dentro deste último, uma cisão entre seus aspectos civil e político. A Declaração de Direitos do Homem senão enquanto cidadão, e este senão enquanto um cidadão burguês: o homem real só é reconhecido sob a forma do indivíduo egoísta; e o homem verdadeiro, sob a forma do citoyen abstrato. De modo que, por isso: os direitos humanos, ao contrário do direito do cidadão, são apenas direitos do membro da sociedade burguesa, do homem egoísta, do homem separado do homem e da comunidade. A sociedade é contraditória e o Estado é chamado para amortecer o choque mantendo a ordem.

Lênin, segundo o professor espanhol Valverde (2014, p. 57), coerente com a posição marxista tradicional, entendia que os regramentos laborais nas economias capitalistas comportam a exploração do trabalhador, sendo uma concessão calculada dos capitalistas para os trabalhadores tolerarem a exploração, e que tal conceituação encontra-se em um folheto de Lênin intitulado “A Lei de multas das fábricas”, datado de 1887.

Habermas (2011, p. 151) expõe uma análise crítica no sentido de que as leis trabalhistas e os contratos coletivos abrem portas para uma colonização do comportamento dos assalariados, que no início mal é percebida, mas que a seguir se alastra e se consolida - o professor Adalberto Moreira Cardoso explica tal posicionamento: 
Mais recentemente, sobretudo depois da teoria do agir comunicativo de Habermas, a literatura alemã vem pondo ênfase em outro aspecto central do direito do trabalho vendo também como elemento fulcral do processo secular de juridificação das relações sociais, isto é, da colonização do mundo da vida (o lugar por excelência do agir comunicativo) pelo direito. E como se o Estado, por meio da produção de regras jurídicas, estivesse limitando a autonomia dos indivíduos e dos grupos em determinar ou defender seus interesses. Note-se que a abordagem é crítica em relação ao direito como aspecto da ordem estatal moderna, ao mesmo tempo em que reconhece seu papel central na vertebração desta mesma ordem, isto é, sua função (o termo é de Habermas) como um dos instrumentos de coesão social (ao lado do dinheiro, do poder e da solidariedade). A abordagem, ademais, tem semelhança com certa leitura liberal do direito (o direito como obstáculo), mas a alternativa não é uma sociedade fragmentada de indivíduos negociando suas posições segundo seus interesses particulares, mas sim uma sociedade cuja identidade é construída por indivíduos dispostos a negociar suas posições originais na busca do entendimento e, possivelmente, do bem comum (CARDOSO, 2001, p. 116).

Óscar Correas (1995, p. 172), autor mexicano marxista, em Crítica da Ideologia Jurídica, aponta o caráter de salvaguardar a produção capitalista do direito do trabalho e ainda que o contrato de trabalho seja uma mera compra de mercadoria negada pela doutrina e que a distinção que ela faz entre contrato de trabalho e contrato civil são mentirosas e apologéticas, ocultadoras do caráter mercantil da força de trabalho.

Se aceitarmos o espaço da social-democracia como legítimo e eficaz até para o trato da desigualdade do mundo, temos de aceitar que um dos seus traços fortes é o equilíbrio entre capital e trabalho, entre o direito do trabalho e o direito da propriedade. E então o modus operandi de tal direito, como Edelman (2016, p. 72) demonstra, está na dialética do abuso do direito - ora prevalece o interesse dos patrões, ora dos empregados. 
Edelman aponta que todo sistema jurídico da social democracia trata-se de um capitalismo garantido pelo direito, que o local da fábrica pertence ao patrão assim como o trabalhador quando nela adentra (a par de proteções à sua personalidade), que tudo é um álibi para exploração capitalista, que a ordem jurídica coloca o homem no lugar da classe, que os direitos individuais reproduzem seus limites na obrigação de não prejudicar o outro, que a ideia de homem (liberdade, igualdade e propriedade privada) é uma astúcia do capital que deu à classe operária uma língua que não é sua.

No contexto do neoliberalismo, os trabalhadores lutam hoje para garantia de suas conquistas históricas - independentemente de que tais direitos não sejam "sua língua" - a dialética do negativo - anteriormente citada - mostra sua face cruel. $\mathrm{O}$ trabalhador quase à beira da inanição dos primórdios do capitalismo conheceu a época de ouro de capitalismo no apogeu da social democracia e do paradigma do Estado Social - e agora conhece a possibilidade de perdas reais ante os discursos dos neoliberais, que responsabilizam as regulamentações trabalhistas pelo desemprego, informalidade e falta de competitividade dos mercados de trabalho e da economia em seu todo.

Voltando aà Era Vargas e fazendo um balanço, para um povo carente em seus direitos - tivemos que a estrutura dos sindicatos "oficiais" cresceu em todo país e a Justiça do Trabalho homogeneizou os direitos trabalhistas mínimos, como salários, condições de trabalho, jornada de trabalho e proteção ao trabalho infantil. Os governos de Dutra, JK e Jânio pouco alteram o quadro dos regulamentos trabalhistas e a ideologia de controle pela legalidade. A posse de João Goulart apresenta momento efervescente da política com possibilidade das chamadas reformas de base com reforma agrária e independência para seguir o país uma linha independente de desenvolvimento teve de ser brutalmente reprimida. 
O golpe militar de 64 trouxe a opção da subserviência ao capital estrangeiro e mudanças profundas na legislação trabalhista: política salarial rígida e fim da estabilidade decenal com a instituição do sistema do FGTS (falava-se em “opção” do trabalhador, mas tal não ocorria na prática pela pressão patronal); a tomada democrática a partir dos anos 80 , permitiu aos sindicatos uma estrutura pronta para engendrar suas lutas, os direitos sociais foram levados ao campo também paulatinamente e igualando-se aos trabalhadores urbanos e, mais recentemente, aos domésticos, tiveram também a equalização de seus direitos.

O Brasil, contudo, ainda possui poder normativo. ${ }^{3}$ Até porque houve uma acomodação dos empresários e dos trabalhadores em resolver suas controvérsias no modelo preconizado pelo Estado-Novo - por meio de peritos - despolitizando por completo a greve, na linguagem de Edelman. O movimento sindical chegou a questionar tal instituto apostando no poder de barganha, mas ele foi mantido.

O modelo de legislação trabalhista no Brasil ainda é o legislado. Os direitos trabalhistas foram ampliados e, em grande parte, constitucionalizados a partir, principalmente, da Constituição de 1988. O marco regulatório, advindo de coação física e ideológica, exprimindo o período autoritário da época varguista, serviu tão bem aos interesses do capital que atravessou anos e Constituições sem grandes mudanças e várias de suas estruturas permanecem como o poder normativo, o sindicato único e o imposto sindical. Sem dúvidas, que diminui a autonomia dos sindicatos, mas mesmo na social-democracia típica, Edelman aponta como, muito manipuladas pelo Estado de Direito, as categorias da linguagem jurídica camuflam a realidade de um direito do trabalho que se ajusta aos interesses da capital.

3 A par das modificações da Emenda Constitucional n. 45, o poder normativo ainda é uma realidade nos casos de greves e em atividades essenciais. 
A Justiça de Trabalho é, por sua vez, na atualidade uma instituição atacada pela lógica neoliberal que não admite intervenções no mercado de trabalho - daí as acusações de ser lenta e paternalista. E a defesa de que os dissídios sejam julgados fora da estrutura do Judiciário, assim como os sindicatos que são acusados de defender interesses corporativos. Estes princípios traduzem a política do liberalismo desde tempos remotos no sentido da desqualificação de qualquer intervenção no mercado de trabalho, seja por intermédio do Estado ou das entidades sindicais.

O sociólogo francês Pierre Bourdieu afirma que os países ligados às leis trabalhistas estatais resistem bem melhor ao "bote" neoliberal:

[...] uma das grandes diferenças entre a França e a Inglaterra é que os ingleses thacherizados descobrem que não resistiram tanto como teriam sido capazes, em grande parte porque o contrato de trabalho era um contrato common law, e não como na França, uma convenção garantida pelo Estado (BOURDIEU, 1998, p. 47).

Em tempos da contraofensiva neoliberal é preciso uma resposta unificadora a tudo isso. Ou seja, combater os desmantelamentos das aquisições democráticas em matéria de legislação social - e faltou a Edelman compreender tal dimensão - inclusive a defesa de tais conquistas não é arcaica, posto que "[...] quando se é levado a defender coisas que de resto quer se transformar, como o serviço público e o Estado nacional, que ninguém pense em conservar como está, ou o Sindicato ou mesmo a "escola pública”, que é preciso a crítica mais impiedosa” (BOURDIEU, 2001, p. 42). Conservar e avançar? Avançar nos limites da social- democracia da legislação ainda existente como defender integralmente o princípio de proibição de retrocesso social, da democratização do espaço fabril, da redução da jornada sem prejuízo aos salários, do combate ao trabalho escravo e infantil, sendo que cada país tem seu avanço próprio em tais temas, o que pode ser ampliado ainda mais. 
A lei burguesa - a par de todo seu fetichismo, dos efeitos perversos, dado que uma astúcia do capital para neutralizar a luta de classe - pode também ser analisada com viés de uma vontade política que de certa forma libertou o trabalho das leis do mercado - claro que isso dentro de limites consideráveis, mas não pode deixar de ser levada em conta também uma conquista civilizatória - hoje ameaçada pela ofensiva neoliberal.

O outro caminho - proposto por Edelman - está na volta das ambições revolucionárias da classe trabalhadora. $\mathrm{O}$ fim da propriedade privada, dos mercados, do trabalho alienante, etc. - bandeiras tradicionais do marxismo. Fique o leitor à vontade - não nos cabe rejeitar ou apoiar tal projeto societário. Em sentido de urgência, contudo, há de se desmascarar a política atual do capital que propõe uma dialética negativa de retorno aos primórdios do mercado de trabalho com remuneração próxima da renda mínima de sobrevivência (tendo de laborar para ganhar um dia de sobrevivência), ausência de leis trabalhistas e desemprego cada vez mais estrutural. A negatividade quanto às leis trabalhistas pelo aspecto mencionado da escamoteação da luta de classes e a perda de referência revolucionária devem ser conjugados com a necessidade dessas leis, sob pena de barbárie. Discursos, acontecimentos e experiências que sejam demonstrados às claras e às escancaras - e que a teoria crítica - a par de suas limitações - não se distancie da presente luta, afinal "aqueles que têm a oportunidade de dedicar sua vida ao estudo do mundo social não podem ficar neutros, distanciados da luta dos quais o resultado será o futuro desse mundo" (BOURDIEU, 2001, p. 7).

\section{CONSIDERAÇÕES FINAIS}

Edelman, de acordo com a tradição marxiana, compreende que a legalização da classe trabalhadora, por meio da legislação trabalhista, representou sua cooptação aos interesses do capital abrindo mão da revolução comunista - abolição de todas as classes sociais. Os direitos traba- 
lhistas são uma "língua" diferente da luta de classe e impõem para os trabalhadores um cálculo de possibilidades de concessões da burguesia que, com isso, contorna a luta de classes e sua possibilidade revolucionária.

Os discursos analisados por Edelman sobre greves e comissões de fábricas, nos anos 70 na França, regida pela social-democracia, não difere dos discursos advindos do regime autoritário dos anos 30 e 40 no Brasil que, ao fim e ao cabo, também guardavam o objetivo maior de contornar a luta de classe e suas ameaças revolucionárias.

O contexto neoliberal atual - em que se ameaça as legislações trabalhistas em todo mundo - impõe a necessidade de defendê-las, mesmo que se considere todo o fetichismo que a representam como anteriormente apontado, pois estão em jogo conquistas históricas dos trabalhadores, mesmo que tal defesa não deixe de apontar que tais leis colonizam os trabalhadores e que a luta maior esteja - como observado por Edelman e pela tradição marxiana - na revolução comunista.

\section{REFERÊNCIAS}

ALBUQUERQUE, Manoel Maurício de. Pequena história da formação social brasileira. 4. ed. Rio de Janeiro: Graal, 1986.

BARTHES, Roland. Aula. Tradução Leyla Perrone-Moisés. São Paulo: Cultrix, 1978.

BOTTOMORE, Tom. Dicionário do pensamento marxista. Tradução Waltensir Dutra. Rio de Janeiro: Zahar, 1983.

BOURDIEU, Pierre. Contrafogos: táticas para enfrentar a invasão neoliberal. Tradução Lucy Magalhães. Rio de Janeiro: Zahar Editor, 1998.

Contrafogos 2: por um movimento social europeu. Tradução André Telles. Rio de Janeiro: Zahar Editor, 2001.

CARDOSO, Adalberto Moreira. A década neoliberal. São Paulo: Boitempo, 2001. 
CORREAS, Óscar. Crítica da ideologia jurídica. Tradução Roberto Bueno. Porto Alegre: Fabris, 1995.

EDELMAN, Bernard. A legalização da classe operária. Tradução Marcus Orione. São Paulo: Boitempo, 2016.

GOMES, Angela Maria de Castro. Burguesia e trabalho: política e legislação social no Brasil 1917-1935. Rio de Janeiro: Campus, 1979.

HABERMAS, Jürgen. A nova obscuridade. Tradução Luiz Repa. São Paulo: Unesp, 2011.

MORAES FILHO, Evaristo de. O problema do sindicato único no Brasil: seus fundamentos sociológicos. São Paulo: Alfa-Ômega, 1952.

NAY, Oliver. Histórias das idéias políticas. Tradução Jaime A. Classen. Petrópolis: Vozes, 2003.

PARANHOS, Adalberto. $O$ roubo da fala: origens da ideologia do trabalhismo no Brasil. São Paulo: Boitempo, 1999.

POCHMANN, Marcio. O emprego na globalização: a nova divisão internacional do trabalho e o caminho que o Brasil escolheu. São Paulo: Boitempo, 2001.

. Nova classe média? O trabalho na pirâmide social brasileira. São Paulo: Boitempo, 2014.

POGREBINSCHI, Thamy. O enigma do politico: Marx contra a política moderna. Rio de Janeiro: Civilização Brasileira, 2009.

VALVERDE, Antonio Martin; GUTIÉRREZ, Fermin; MURCIA, Joaquin Garcia. Derecho del trabajo. 23. ed. Madrid: Tecnos, 2014.

WOLKMER, Antonio Carlos. Constitucionalismo e direitos sociais no Brasil. São Paulo: Acadêmico, 1989. . História do direito no Brasil. Rio de Janeiro: Forense, 1998.

Recebido em: 15/7/2016

Revisões requeridas em: 10/10/2016

Aceito em: 15/11/2016 